\title{
Consumer satisfaction with pharmaceutical care in Slovak community pharmacies Spokojnost' klientov lekární s lekárenskou starostlivostou na Slovensku
}

Comenius University in Bratislava, Faculty of Pharmacy

Department of Organisation and Management in Pharmacy
Univerzita Komenského v Bratislave,

Farmaceutická fakulta,

Katedra organizácie a riadenia farmácie

Registered 29 October 2014, accepted 17 December 2014

\begin{abstract}
The aim of this pilot study was to evaluate consumer satisfaction with pharmaceutical care provided in community pharmacies at the region level. Expectations and opinions of consumers were also confronted with the assumptions of pharmacists. Up to $82.0 \%$ of consumers confirmed their satisfaction with the care given to them by the pharmacist. A key factor of consumer satisfaction has been the professional (78.7\%) and human approach (83.5\%) of the pharmacist. A total of $73.6 \%$ of consumers in the survey accepted the pharmacist as an expert in medicines. The pharmacist's self-evaluation was more negative. Monitoring and evaluation of consumer satisfactory with pharmaceutical care is not only essential for improvement of the quality of the healthcare system and for the implementation of pharmaceutical care focussed on the patient, but it may influence the economic and financial outcomes of entities providing pharmaceutical care in community pharmacies.

Slovak Ciel’om tejto pilotnej štúdie bolo zhodnotit’ spokojnost' zákazníkov s lekárenskou starostlivostou poskytovanou vo verejných abstract lekárňach na lokálnej úrovni. Očakávania a názory zákazníkov boli zároveň porovnané s predpokladmi lekárnikov. Až 82,0\% zákazníkov potvrdilo svoju spokojnost’ so starostlivostou, ktorú im poskytuje lekárnik. Ako klúčový faktor spokojnosti zákazníkov sa ukázal profesionálny $(78,7 \%)$ a l'udský prístup $(83,5 \%)$ lekárnika. $73,6 \%$ zákazníkov v našom prieskume akceptovalo lekárnika ako odborníka na lieky. Sebahodnotenie lekárnikov bolo negatívnejšie. Monitoring a hodnotenie spokojnosti zákazníkov s lekárenskou starostlivostou je nevyhnutné nielen pre zlepšenie kvality systému zdravotnej starostlivosti a pre implementáciu lekárenskej starostlivosti orientovanej na pacienta, ale môže ovplyvnit’ ekonomické a finančné výsledky subjektov poskytujúcich lekárenskú starostlivost' vo verejných lekárňach.
\end{abstract}

Keywords Consumer-Pharmacist-Satisfaction-Pharmaceutical Care-Community Pharmacy

Klúčové spotrebitel'-lekárnik-spokojnost'-lekárenská starostlivost'-verejná lekáreň

slová:

\section{INTRODUCTION}

Pharmaceutical care in Slovakia is legislative defined as one of the forms of provided healthcare services, and is explained as a set of work activities performed by healthcare workers, and includes the provision of medicines, medical devices and dietary foods in order to prolong life of an individual, raise the quality of his/her life and healthy development of the future generations (Ministry of Health. Law on pharmacy, No 576/2004). It is provided under permission in health facilities of pharmaceutical care, such as community pharmacy, a branch of community pharmacy, a hospital pharmacy and a dispensary of medical devices (Ministry of Health. Law on pharmacy, No 362/2011). The content of pharmaceutical care is defined by law. It includes quality assurance, storage, preparation, control and supply of medicines, medical devices and dietary foods including internet dispensing and also involves providing professional information and supervision of medicines and medical devices. In 2006, the new concept of healthcare in Slovakia came in the field of community pharmacy and clinical pharmacy (Ministry of Health. The concept of healthcare in the field of clinical pharmacy, 2006). The attention of both concepts is focused on clinical pharmacy activities in Slovakia according to European and global orientation, in the meaning of 'pharmaceutical care' (Mikeal et al, 1975, Hepler \& Strand, 1990, FIP Statement of professional 
standards pharmaceutical care, 1998). The pharmaceutical care slightly deviates from orientation on the traditional dispensing and sale of medicines. It begins to concentrate on the patient, although there are various barriers that hamper its implementation in Slovakia, as in other countries (Foltan, 2012, Magulova \& Foltanova, 2008).

Slovakia is an independent country and a member of the European Union with a total population of around 5.4 million inhabitants (Sight of the Regions of Slovakia 2008-2012, 2014) and 1730 community pharmacies (Health Yearbook 2012 , 2014). The pharmacy to population ratio in Slovakia is approximately 1:3128. The entities providing pharmaceutical care in Slovakia are regulated by legal norms, allowing them to choose the legal form of business - either sole proprietorships or partnerships (Ministry of Justice. Coll. Act on Small Business, No. 455/1991).

The success and survival of entities in the market environment depends on many factors. Entities are providing pharmaceutical care business in strict and restrictive legislative and economic environment (Malovecka et al, 2014). The current offer of pharmaceutical care in community pharmacies exceeds demand; the consumer has a choice, therefore, consumer's satisfaction begins to play an important role in providing of pharmaceutical care. This situation creates an increasingly important space to 'fight for consumers.' It should be taken into account that consumer satisfaction with the community pharmacy is subjective and reflects the care provided, as well as his preferences and expectations (Kucukarslan \& Schommer, 2002). Studies have shown that the consumer can be more satisfied if the aim of pharmaceutical care is focused on a patient. That results in improvement of patient's compliance and rise in the quality of life (Andrade et al, 2009, Bernsten et al, 2001, Silva et al, 2012). We believe that consumer satisfaction can significantly contribute and influence the economic and financial situation of the community pharmacies.

The evaluation of care provided in community pharmacies in relation to the consumer satisfaction is rare in Slovakia. This work has the character of a pilot study carried out at the region level to monitor consumer satisfaction with the pharmaceutical care provided in community pharmacy. In addition, the aim was the confrontation of the consumers' and pharmacists' reviews and evaluations.

\section{METHODS}

To evaluate consumer satisfaction, a voluntary anonymous questionnaire survey was conducted in community pharmacies in a randomly selected town in Slovakia in the time span from November to December 2012. The survey was led in two parallel lines - consumers' line and pharmacists' line. From 13 community pharmacies (62\% of total amount), 134 consumers and 20 pharmacists participated in the survey. Various literature sources were reviewed to develop the self- administered questionnaire (Larson et al, 2002, Traverso et al, 2007). The content of the questionnaire was identical for both lines for the purpose of comparison. The results were processed by Microsoft Windows 7 and Excel.

\section{RESULTS}

There were 134 consumers randomly surveyed (Table 1). The total number of fully completed questionnaires was 129; five questionnaires were incomplete and therefore, not included in the final analysis. There were 20 pharmacists surveyed (Table 2). The total number of fully completed questionnaires was 20. Afterwards, all questionnaires were further evaluated.

Table 1. The consumers' socio-demographic profile $(n=129)$

\begin{tabular}{|c|c|c|}
\hline & & Together (\%) \\
\hline \multirow{2}{*}{ Gender } & Women & $86(66.6 \%)$ \\
\hline & Men & $43(33.4 \%)$ \\
\hline \multirow{3}{*}{ Age (years) } & $\leq 35$ & $48(37.2 \%)$ \\
\hline & $36-55$ & $53(41.1 \%)$ \\
\hline & $>55$ & $28(21.7 \%)$ \\
\hline \multirow{3}{*}{ Education } & Basic & $12(9.3 \%)$ \\
\hline & Secondary & $71(55.0 \%)$ \\
\hline & Higher & 46 (35.7\%) \\
\hline \multirow{3}{*}{$\begin{array}{c}\text { Taking } \\
\text { medication }\end{array}$} & Regular, long-term & 49 (38.0\%) \\
\hline & Occasionally & $29(22.5 \%)$ \\
\hline & Rarely & $51(39.5 \%)$ \\
\hline \multirow{3}{*}{$\begin{array}{l}\text { Number of } \\
\text { attending } \\
\text { pharmacies }\end{array}$} & 1 & 25 (19.4\%) \\
\hline & $2-3$ & $46(35.7 \%)$ \\
\hline & $>3$ & $58(44.9 \%)$ \\
\hline
\end{tabular}

Table 2. The pharmacists' socio-demographic profile $(n=20)$

\begin{tabular}{|c|c|c|}
\hline \multirow{2}{*}{ Gender } & \multicolumn{2}{|c|}{ Together (\%) } \\
\hline \multirow{2}{*}{ Age (years) } & Women & $17(85.0 \%)$ \\
\cline { 2 - 3 } & Men & $3(15.0 \%)$ \\
\cline { 2 - 3 } & $\mathbf{3 5 5}$ & $9(45.0 \%)$ \\
\cline { 2 - 3 } & $\mathbf{3 6 - 5 5}$ & $7(35.0 \%)$ \\
\hline \multirow{3}{*}{ Location of pharmacies } & $\begin{array}{c}\text { Near medical } \\
\text { equipment }\end{array}$ & $14(70.0 \%)$ \\
\cline { 2 - 3 } & $\mathbf{0 t h e r}$ & $6(30.0 \%)$ \\
\hline \multirow{2}{*}{$\begin{array}{c}\text { The average number } \\
\text { of visitors per day in } \\
\text { community pharmacy }\end{array}$} & $\mathbf{2 1 0 0}$ & $3(15.0 \%)$ \\
\cline { 2 - 3 } & $\mathbf{1 0 1 - 2 0 0}$ & $8(40.0 \%)$ \\
\cline { 2 - 3 } & $\mathbf{2 0 0}$ & $9(45.0 \%)$ \\
\hline
\end{tabular}




\subsection{Consumer satisfaction with pharmaceutical care}

To evaluate the total consumer satisfaction with the visit of community pharmacies, a four-speed range of responses was used ('always completely satisfied', 'mostly satisfied,' 'dissatisfied sometimes' and 'often dissatisfied'). Nearly $71.0 \%$ of consumers were mostly satisfied, $11.0 \%$ always completely satisfied and only $18.0 \%$ were dissatisfied when assessing the total satisfaction with provision of pharmaceutical care in pharmacy. Expressed satisfaction was further analysed according to gender of respondents, their age, education and number of pharmacies visited (Table 3). Men ( $90.5 \%$ versus $77.6 \%$ for women), respondents under 35 years $(83.3 \%)$ and over 55 (89.3\%) showed greater degree of satisfaction (answers 'always satisfied' or 'mostly satisfied'). Respondents with university degree (91.1\%) showed the highest satisfaction. The total satisfaction insignificantly decreased with respect to the number of pharmacies visited. It can thus be concluded that, in our group of respondents, gender, age, education and number of pharmacies visited had no significant effect on the expression of the total satisfaction with the provided pharmaceutical care. We can state that men, older respondents (over 55 years), respondents with higher education and visiting one pharmacy showed a higher level of satisfaction.

In the next section of the questionnaire, consumers had to mark a degree of their satisfaction ('very satisfied', 'average satisfied', 'dissatisfied') with 12 selected characteristics of provided pharmaceutical care in community pharmacies (Table 4). Respondents expressed the most significant satisfaction ('very satisfied') with the time given to them directly by the pharmacist (61.4\%), professional manners of a pharmacist (54.3\%), supply and availability of supplementary products in the pharmacy attended (50.4\%) and space in which consumers or patients communicate directly with the pharmacist (49.2\%). Respondents expressed the most obvious dissatisfaction with the offer of generic substitution by the pharmacist (18.0\%) and with the offer of discounts and loyalty schemes (23.9\%).

Also assessed were factors that were significant and insignificant for consumer satisfaction in providing pharmaceutical care (respondents had to mark three proposed options). Consumers' responses were compared with responses from pharmacists (Table 5). Consumers tagged as the essential factors of their satisfaction human (83.5\%) and professional approach of the pharmacist (78.7\%) and pharmacists also identified these equally. The time (short waiting time $37.8 \%$ ) was important for consumer satisfaction but only $10.0 \%$ of pharmacists considered it as important for consumers. According to pharmacists, availability of medicines $(75.0 \%)$ was important factors for consumer satisfaction, the consumers did not consider it as important (27.6\%). Promotional materials $(63.6 \%$ consumers versus $50.0 \%$ pharmacists) and self-service area $(72.2 \%$ pharmacists versus $27.1 \%$ consumers) were identified as irrelevant factors for consumer satisfaction.

Interviewed pharmacists identified major changes in the prices of medicines $(75.0 \%)$, high co-payments for drugs $(70.0 \%)$, storage policy in the pharmacy $(45.0 \%)$ as the barriers that prevent pharmacists from satisfying consumers. Further, pharmacists selected administrative work in the pharmacy, lack of time, space and privacy, lack of comprehensive information for patient, inability to apply financial benefits to patients as other cooperating factors (30\%). Lack of professional information about the products and dissatisfaction with working conditions were not marked.

\subsection{Consumer perception of community pharmacists}

The last part of the survey investigated the opinion and perception of the pharmacist by the consumers. Evaluation

Table 3. The total consumer satisfaction with pharmaceutical care provided in a community pharmacy

\begin{tabular}{|c|c|c|c|c|}
\hline $\begin{array}{c}\text { Consumer satisfaction with } \\
\text { pharmaceutical care provided } \\
\text { in a community pharmacy } \mathbf{n}(\%)\end{array}$ & Always satisfied & Mostly satisfied & $\begin{array}{c}\text { Sometimes } \\
\text { dissatisfied }\end{array}$ & Often dissatisfied \\
\hline Men & $\mathbf{1 4 . 3}$ & $\mathbf{7 6 . 2}$ & 20.0 & 2.4 \\
\hline Women & 9.4 & 68.2 & 7.1 & 2.4 \\
\hline Age up to 35 years & $\mathbf{1 2 . 5}$ & $\mathbf{7 0 . 8}$ & 14.6 & 2.1 \\
\hline Age 36-55 years & 7.8 & 68.6 & 19.6 & 3.9 \\
\hline Age over 55 years & $\mathbf{1 4 . 3}$ & $\mathbf{7 5 . 0}$ & 10.7 & 0.0 \\
\hline Primary education & 25.0 & 58.3 & 16.7 & 0.0 \\
\hline Secondary education & 8.7 & 66.7 & 20.3 & 4.3 \\
\hline Higher education & $\mathbf{8 . 9}$ & $\mathbf{8 2 . 2}$ & 8.9 & 0.0 \\
\hline Regular visit to one pharmacy & $\mathbf{1 6 . 0}$ & $\mathbf{7 5 . 0}$ & 8.3 & 4.2 \\
\hline Visiting 2-3 pharmacies & 8.5 & 70.2 & 19.2 & 2.1 \\
\hline Visiting more than 3 pharmacies & 10.9 & 69.6 & 16.1 & 1.8 \\
\hline
\end{tabular}


Table 4. Consumer satisfaction with some parameters of provided pharmaceutical care

\begin{tabular}{|c|c|c|c|}
\hline Consumer satisfaction with some parameters of pharmaceutical care $\mathbf{n}(\%)$ & $\begin{array}{c}\text { Very } \\
\text { satisfied }\end{array}$ & $\begin{array}{l}\text { Average } \\
\text { satisfied }\end{array}$ & Dissatisfied \\
\hline Spatial arrangement and appearance of pharmacy & 44.2 & 55.8 & 0.0 \\
\hline Pharmacist's information about medicines and other product range & 45.3 & 51.6 & 3.1 \\
\hline Pharmacist's information about your illness and its treatment & 31.2 & 64.0 & 4.8 \\
\hline Availability of products in the pharmacy attended & 38.3 & 56.3 & 5.4 \\
\hline Supply and availability of supplementary products in the pharmacy attended & 50.4 & 46.5 & 3.1 \\
\hline The time that you have to spend waiting until you get to the pharmacist & 42.6 & 48.8 & 8.5 \\
\hline The time that pharmacist serves and communicates only with you & 61.4 & 36.2 & 2.4 \\
\hline The space in which you communicate directly with the pharmacist & 49.2 & 46.0 & 4.8 \\
\hline Professional manners of the pharmacist & 54.3 & 42.6 & 3.1 \\
\hline Interest and empathy of the pharmacist about your health needs & 42.5 & 52.0 & 5.5 \\
\hline Offer of generic substitution by the pharmacist & 29.5 & 52.5 & 18.0 \\
\hline Offer of various discounts and loyalty schemes & 33.7 & 42.4 & 23.9 \\
\hline
\end{tabular}

Table 5. Significant and insignificant factors for consumer satisfaction ( $n=129$ consumers, $n=20$ pharmacists)

\begin{tabular}{|c|c|c|c|c|}
\hline \multirow{2}{*}{ Factors for consumer satisfaction $\mathbf{n}(\%)$} & \multicolumn{2}{|c|}{ Significant factors } & \multicolumn{2}{|c|}{ Insignificant factors } \\
\hline & Pharmacists & Consumers & Pharmacists & Consumers \\
\hline Professional approach & 85.0 & 78.7 & 5.6 & 0.0 \\
\hline Human approach towards patients & 85.0 & 83.5 & 0 & 0.0 \\
\hline More privacy for discussion with pharmacist & 10.0 & 7.9 & 5.6 & 22.0 \\
\hline Self-service space in community pharmacy & 0.0 & 6.3 & 72.2 & 27.1 \\
\hline Short waiting time & 10.0 & 37.8 & 0 & 3.4 \\
\hline Provision of discounts & 5.0 & 15.0 & 16.7 & 8.5 \\
\hline Generic substitution & 20.0 & 30.7 & 0.0 & 6.8 \\
\hline Availability of drugs & 75.0 & 27.6 & 0.0 & 3.4 \\
\hline The possibility to order products & 0.0 & 2.4 & 27.8 & 40.7 \\
\hline Promotion materials & 0.0 & 0.0 & 50.0 & 63.6 \\
\hline Opening hours & 0.0 & 3.1 & 16.7 & 11.9 \\
\hline Other services & 10.0 & 7.9 & 11.1 & 11.0 \\
\hline
\end{tabular}

of the consumers was positive, opposed to opinion of the pharmacists. A total of $73.6 \%$ of consumers accept the pharmacist as a professional expert in medicines, medical devices and other stock available at the pharmacy; $65.1 \%$ as a consultant and an expert on issues of health, disease, treatment and prevention; $50.4 \%$ accept pharmacist together with a doctor to achieve patients health. On the other hand, $21.7 \%$ of consumers said that the pharmacists are 
only sellers of medicines and $10.9 \%$ of them think that the pharmacists' main aim is to make a profit and not patient care. Paradoxically, the answers of pharmacists are critical. Up to $50.0 \%$ of pharmacists believe that consumers perceive them as sellers of drugs and $30.0 \%$ of pharmacists consider that consumers think that they are focused on profit rather than patients' health. Only $50.0 \%$ of pharmacists believe that consumers perceive them as professional experts, and $55.0 \%$ as consultants in health matters.

\section{DISCUSSION}

Generally, consumer satisfaction is an important measure of how well services are provided (Kucukarslan \& Schommer, 2002). Community pharmacists have difficult choice in balancing the commercial and professional aspects of their profession. In Slovakia, like in other countries, community pharmacy runs on a profit basis and is not subsidised by the state; therefore, if the community pharmacy wants to survive, profit is a must. Community pharmacy has the hard dual role - commercial and professional. As the solution of this duality may be consistent consumer-centred orientation, which should in turn provide financial stability.

Consumer satisfaction with the pharmaceutical care provided in community pharmacies in Slovakia has not been the subject of serious analysis. Some partial conclusions result from the nationwide survey - the project Excellent Pharmacy (Snopková, 2011), which documented 66.0\% overall patient satisfaction with the care provided at the pharmacy. Our observed outcome (total satisfaction was $82.0 \%$ and consisted of $-11.0 \%$ 'always completely satisfied' and $71.0 \%$ 'mostly satisfied') is even higher, possibly resulting from incomplete anonymity of respondents, the survey site (small town) and socio-demographic status of respondents. Similarly, consumer research in the U.S. in 2001 showed high satisfaction (85.0\%) with care in public facilities at the outlay of recipe (Stergachis et al, 2002). The total consumer satisfaction was reflected in the assessment of 12 selected parameters with which consumers were confronted in the provision of pharmaceutical care. Respondents rated very positive professional approach of the pharmacist and the time devoted to them directly. Similarly, Ried identified that the greatest impact on the total patient satisfaction was from personal attention dedicated by the pharmacist to the patient (Ried et al, 1999).

The main aim of the presented study was to show, for the pharmacists to satisfy the consumers, they must know the expectations and perceptions of the consumers. Unless consumers' expectations and perceptions are not identified, all the activities could be carried out in the wrong direction. Pharmacists very well know what the consumer expects to be satisfied with the healthcare provided in pharmacy. Pharmacists together with consumers identified that a crucial moment for consumer satisfaction is a professional and human approach. However, the results also showed the differing views of pharmacists and consumers - such as relation to the waiting time, availability of medicines, generic substitution, offers and discounts, self-service area, opening hours, and so on. The survey also showed that pharmacists are perceived to be more critical than they are accepted by the consumers. Provision of pharmaceutical care includes elements of the business (for which profit is legitimate and necessary condition), while they provide a highly specialised activity, which is carried out in a strictly regulated environment of drugs by the state. Pharmacists should pay more attention to self-assessments, position in society, and while it would be appropriate, educate consumers about the 'background' work of a pharmacist. Seamless availability of medicines, medical devices, dietary supplements and various supplementary products in pharmacies and other services in terms of actual pharmaceutical care and not only activities associated with ensuring the product within the legislative definition, bring ever increasing demands on the operation of pharmacies and pharmacists' work. Unfortunately, the environmental conditions are far from being in line with the further development of care provided in a pharmacy despite the willingness of pharmacists and patients themselves.

\section{CONCLUSION}

The primary goals of this pilot study, using a questionnaire survey, was to determine consumer satisfaction with care provided in a community pharmacy, compare consumers' and pharmacists' opinion and seek common or different approaches. In the wider context, the study highlights the importance of consumer satisfaction in reconciling professional and commercial role of the community pharmacists. The survey results have brought the following findings and conclusions. The evaluation of consumer satisfaction with the provided care carried in community pharmacies in Slovakia is not utilised in practice; however, it is proven that it contributes to improving the quality of healthcare provided as well as the financial situation of the community pharmacy. Comparisons of consumers' expectations and assumptions of pharmacists can help meet satisfaction of consumers and ultimately affect the functioning of community pharmacy and the healthcare system. The pharmacist is fully accepted healthcare professional. The pharmacists' ideas about their profession and the public perception coincide in the basic intentions, but the commercialisation of the system caused that the intentions diverge from expectations. 
[1] Andrade TU, Burini DM, Mello MO, Bersacula NS, Saliba RAD, Bravim FT and Bissoli NS. Evaluation of the satisfaction level of patients attended by a Pharmaceutical Care Program in a Private Communitarian Pharmacy in Vitória (ES, Brazil). Braz J Pharm Sci. (2009) 45 (2): 349-355.

[2] Bernsten C, Bjorkman I, Caramona M, Crealey G., Frokjaer B, Grundberger E, Gustafsson T, Henman M, Herborg H, Hughes $C$, McElnay J, Magner M, van Mil F, Schaeffer M, Silva S, Sondergaard $B$, Sturgess I, Tromp D, Vivero $L$ and Winterstein A. Improving the well-being of elderly patients via community pharmacy-based provision of pharmaceutical care: a multicentre study in seven European countries. Drugs Aging. (2001) 18 (1): 63-77.

[3] FIP Statement of professional standards pharmaceutical care. Council of the International Pharmaceutical Federation (FIP), Hague, Netherlands (1998) 1-3.

[4] Foltan V (ed). Vybrané aspekty lekárenskej starostlivosti (in Slovak). 1st ed. Linwe / KRAFT, s.r.o. Bratislava (2012) 9-23.

[5] Hepler CD and Strand LM. Opportunities and responsibilities in pharmaceutical care. Am J Hosp Pharm. (1990) 47: 533-543.

[6] Kucukarslan SN and Schommer JC. Patients' expectation and their satisfaction with pharmacy services. J Am Pharm Assoc. (2002) 42 (3): 489-496.

[7] Larson LN, Rovers JP and MacKeigan LD. Patient satisfaction with pharmaceutical care: update of a validated instrument. J Am Pharm Assoc. (2002) 42 (1): 44-50.

[8] Magulova L and Foltanova T. Pharmaceutical care and its application in clinical practice. Clin Pharmacol Pharm. (2008) 22 (4): 161-164.

[9] Malovecka I, Minarovic I, Minarikova D, Lehocka L, Snopkova M and Foltan V. Globalization and its impact on pharmacy services in the Slovak Republic. Czech and Slovak pharmacy (2014) 63 (1): 40-47.

[10] Mikeal RL, Brown TP, Lazarus HL and Vinson MC. Quality of pharmaceutical care in hospitals. Am J Hosp Pharm. (1975) 32: 567-574.
[11] Ministry of Health. Law on pharmacy. Official Journal of Ministry of Health Slovak republic No. 576/2004 Coll. Act. (in Slovak language).

[12] Ministry of Health. Law on pharmacy. Official Journal of Ministry of Health Slovak republic No. 362/2011 Coll. Act (in Slovak language).

[13] Ministry of Health. The concept of health care in the field of clinical pharmacy. Official Journal of Ministry of Health of Slovak republic, Special Edition. (2006) 54: 3-10.

[14] Ministry of Justice. Official Journal of Ministry of Justice Slovak republic No. 455/1991 Coll. Act on Small Business (in Slovak language). Recent actualization 2014.

[15] National Health Information Center. Health Yearbook 2012. Bratislava (2014) 118.

[16] Ried LD, Wang F, Young $\mathrm{H}$ and Awiphan R. Patients' satisfaction and their perception of the pharmacist. J Am Pharm Assoc. (1999) 39 (6): 835-842.

[17] Silva GMS, Chambela MC, Sousa AS, Sangenis LHC, Xavier SS, Costa A R, Brasil PEA, Hasslocher-Moreno AM and Saraiva RM. Impact of pharmaceutical care on the quality of life of patients with Chagas disease and heart failure: randomized clinical trial. Trials (2012) 13: 244. doi:10.1186/1745-6215-13-244.

[18] Snopkova M. Health and pharmaceutical care in Slovakia. Pharmacy List. (2011) 11: 14-15.

[19] Stergachis A, Maine LL and Brown L. The 2001 national pharmacy consumer survey. J Am Pharm Assoc. (2002) 42: 568-576.

[20] Statistical Office of the Slovak Republic. Sight of the Regions of Slovakia 2008-2012 Headquarters Bratislava (2014) 14.

[21] Traverso ML, Salamano M, Botta C, Colautti M, Palchik V and Perez B. Questionnaire to assess patient satisfaction with pharmaceutical care in Spanish language. Int $J$ Quali Health Care. (2007) 19 (4): 217-224. 